\title{
PUBERTY BLUES AND THE REPRESENTATION OF AN AUSTRALIAN COMPREHENSIVE HIGH SCHOOL
}

\author{
JOSEPHINE MAY \\ University of Newcastle, NSW
}

An examination of cinematic representations of Australian education over time forms one of author's ongoing projects. This line of research overall is based on a number of foundational questions, the most basic of which is: what can the study of film add to historical research and the writing of history about education in Australia? So far my studies have suggested a number of points. First, in collecting the details of Australian films that concern education, youth and childhood (not yet complete), I have established that Australian school education has been a well visited topic for Australian film-makers. This fact points to the importance of schooling as an institution in the national life, an importance not so readily represented in the wider writing of Australian historical narratives. In another study I have shown how cinematic representations of nineteenth century schools were linked in the 1970 s to explorations of Australian national identity. ${ }^{1}$ Further in a recent study of silent screen images of education from the turn of the century until 1930, I have argued that images of mass education (graphically conveyed for example by busy playgrounds and massed children) in the opening decades of the twentieth century were an important way to imagine the modernising society. Schooling was represented as a field of desire for national fitness, order and fulfilment in these early films. ${ }^{2}$ My hypothesis at this early stage of the project regarding the question 'what can the study of film add to historical research and the writing of history about education in Australia?' is that cinema offers education historians access to powerful vernacular cinematic imaginings about the nature, role and impact of education in Australia, and in studying these representations over time, we should be able to outline changes and continuities in these imaginings. Analyses of filmic representations then should amplify and, perhaps modify, what has been claimed by more conventional historical methodologies based on static forms of evidence.

In this article I examine one film, Puberty Blues, directed by Bruce Beresford in 1981. According to the Australian Film Commission, the film is number forty four of the top Australian films at the Australian Box Office from 1966 to 2005 having earned over three million dollars. The view put here is that this film throws light on the history of the comprehensive coeducational high school at a particular moment. ${ }^{3}$ The article maintains that Puberty Blues pursues a damning representation of the ineffectual and irrelevant nature of school life for the students it features. This unsettling film shows the comprehensive coeducational secondary school, itself a product of a middle class vision of the civil society, to be failing in its promise of extending 'respectable' and

1 J. May, 'Imagining the secondary School: the "pictorial turn" and representations of secondary schools in two Australian feature films of the 1970s', History of Education Review, vol. 35, no. 1, pp. 13-22; J. May, 'Engaging the history of Australian education on silent film: the female teacher as object of desire.' Paper presented at the Australian Historical Association, 2007 Regional Conference, Engaging Histories, University of New England, Australia; J. May, 'Insistent bodies versus the rule: the devil's playground as national cinema' Journal of Interdisciplinary Gender Studies Vol. 10, no.1, 2006, pp. 121-143.

2 J. May, 'National fitness and schools between the wars: some representations of schooling in Australian silent film,' (under review).

3 The high school in the book Puberty Blues (Picador, 2002) is based on Sylvania High School, a co-educational comprehensive high school established in 1970. See the school's website at

http://www.sylvania-h.schools.nsw.edu.au/.

History of Education Review, vol. 37, no. 2, 2008, pp. 61-67 
materially aspirant middle class values to youth. It is suggested that the decline in patronage of the public coeducational comprehensive school by the middle class and aspiring others may in part be attributable overall to the powerful negative images of schools such as those in Puberty Blues that have widely circulated in Australian and Anglophone popular culture, especially in feature film. ${ }^{4} \mathrm{It}$ also hypothesises that the middle class flight from the comprehensive high school may be in part attributable to the fact that some of their children may have 'deserted' the schools first.

\section{Puberty Blues (Beresford, 1981)}

Puberty Blues has been described as a nostalgic coming of age, or rites of passage, feminist film. ${ }^{5}$ The film is based on the novel by two teenage girls, Kathy Lette and Gabrielle Carey, and apparently reflects their autobiographical experiences of growing up in Sydney in the late 1970s. ${ }^{6}$ Set in the beachside suburb of Sylvania Waters, the narrative centres on two girls, Debbie Vickers and Sue Knight, as they eagerly manoeuvre their way into the mindless sexual oppression of the masculinist surfie subculture. It was difficult for the filmmakers to find a school to film in Sylvania Waters because of the reputation of the book. Margaret Kelly, co-producer, said at the time:

The schools are most antagonistic because they think the authors have given Sylvania High, in particular, a very bad name ... none of the schools in the area wanted to know about us. ${ }^{7}$

Eventually the Department of Education agreed that the film could be shot west of the Cooks River and James Cook Boys High School in the Sydney suburb of Kogarah consented. Some of the real students of the school featured in some scenes. ${ }^{8}$

Puberty Blues shows in anthropological detail, ${ }^{9}$ Debbie and Sue's first encounters with drugs, first relationships with boys and first sexual experiences - and gives sustained glimpses of their secondary schooling. The protagonists are basically healthy young women, bright, well brought up, with disposable incomes (the source of which is never explained) and with attentive middle class parents. All this makes their desire to enter the vacuous and poisonous Greenhills gang so mystifying in the first place. The countercultural revolution of the 1960s with its politicisation of youth seems to have been translated without any of its political content into the mindless subcultural hedonism of the 1970s. ${ }^{10}$ Whereas, as Speed has commented, the rites-of-passage film 'is inclined to disavow the immediacy and, at times, the vulgarity of youth culture', ${ }^{11}$ the 'nostalgia' in Puberty Blues is hard edged and the vulgarity of the past is fully depicted. The film shows the barbarisms of surfie

4 There are many other films that represent secondary coeducational comprehensive schools in a negative light, for example, Blackboard Jungle (USA, 1955), Carrie (USA, 1976), To Sir With Love (UK/USA, 1966), Up the Down Staircase (USA, 1967), The Breakfast Club (USA, 1985), Dangerous Minds (USA, 1995), The Heartbreak Kid (Aust., 1983).

5 L. Speed, 'You and me against the world: revisiting Puberty Blues', Metro Magazine, no. 140, 2004, pp. 5460, p.54.

$6 \quad$ K. Lette and G. Carey, Puberty Blues, Sydney, Picador, 2002.

7 Notes on Puberty Blues (1981) http://wwwmcc.murdoch.edu.au/ReadingRoom/film/dbase/2006/puberty. doc. (accessed 27 November 2007). See also N. Scholfield, Puberty Blues Sydney, Currency Press \& Screensound Australia, 2004, p. 30.

8 Scholfield, Puberty Blues, 2004, p. 30.

9 L. Speed, 'When the sun sets over suburbia: class and subculture in Bruce Beresford's Puberty Blues' Continuum: Journal of Media and Cultural Studies, vol. 20, no.3, September 2006, pp. 407-418, p. 413. Film historian Tom O'Regan observed this tendency of 'othering' of Australian culture in some Australian films via an anthropological approach.

10 Strange cited in L. Speed, 'Tuesday's gone: the nostalgic teen film', Journal of Popular Film and Television, vol. 26, no.1, Spring 1998, pp. 24-33. See also H. Giroux, 'Youth and the politics of representation: response to Thomas Hatch's "If the 'Kids' Are Not 'Alright', I'm Clueless"', Educational Researcher, May 1997, pp. 27-30.

11 Speed, 'Tuesday's gone 1998', p. 26. 
subculture, and the emptiness of middle class suburban materialist lifestyle, with a kind of forensic glee. It also lays bare the ineffectual nature of the comprehensive high school.

In Puberty Blues the action takes place in three main types of space: the interior spaces of various suburban middle class family homes, the exterior transitional spaces of car, beach, park and street, and third, the various spaces of the high school. Thus far in the literature the first two spaces have been discussed. For example, the film has been explored employing three analytic approaches: gender, specifically regarding its alleged feminist message (disputed here); class, specifically its representation of middle class suburban domestic culture; ${ }^{12}$ and youth culture, specifically surfie subculture on Cronulla Beach in the 1970s. None of these analyses however have examined the third main space in the film - that of the high school, scenes of which occupy a little over one eighth of the film's running time. This article begins to remedy this oversight, and specifically reflects on the representation of teachers, students, classroom and other facets of school and Australian life given both vision and voice in Puberty Blues (1981). All three aspects are rendered through the perspective of the students, especially via the main character of Debbie Vickers (Nell Schofield). The film thus purports to present a student-centred analysis of Australian schooling at a particular moment and through a particular subcultural frame.

\section{The school, students and teachers in Puberty Blues}

The action in Puberty Blues turns to the school immediately following the short three minute set-up of the film that shows a wide shot of the crowded Cronulla Beach in the high summer, as two teenage girls, Debbie and Sue (Jad Capelja), pick their way among the throng to reach the 'cool' end where the Greenhills surfie gang reign supreme. ${ }^{13}$ In the next scene it is morning, Debbie Vickers in school uniform leaves her comfortable suburban home that she shares with her housewife mother, white collar worker father and younger sister, for the bus stop and school. This narrative positioning of the school at the front of the film underscores its importance as a context for a story about Australian teenagers. Teenage life is shown as both facilitated and circumscribed by schooling. Overall, rather than receiving an education, Debbie and her friends experience school as a socialising space for meeting up with each other. ${ }^{14}$ Both formal and informal curricula are to be subverted in any way necessary for the pursuit of peer connection, validation and mutual education about the things that matter to them: the opposite sex, sexual interaction, drugs, surfing and the beach.

On the bus, we are immediately alerted to 'jungle' of student culture. In a very short space the girls are shown as boy-crazy, physically violent with one another (Debbie and Cheryl [Leander Brett] have a fight in the aisle), and as cheats, having written answers on their upper legs ready for their school history examinations. The next scene shows the students moving from the loosely supervised area of the bus, to the closely supervised examination hall. Here the extent of the

12 Puberty Blues (1981) is made in the 'social landscape' tradition in Australian contemporary film making. It focuses on the suburban lives of the Australian middle class. According to Speed (2006:41), the film 'foreshadowed a proliferation of later films and television series that centre on the Australian middle class ... as well as prefigures television series that focus on youthful characters and suburban locations'. And in which it must be said high schools figure prominently. For example, Erinsborough High is a fictional high school that has been in 'operation' since 1985 in the popular Australian soap opera Neighbours and Summer Bay High School in Home \& Away began in 1988 - both schools cry out for analysis.

13 At times we almost lose sight of the pair in the crowd, only to have them gradually fill the screen and come into sharp focus. This opening sequence sets up the premise: individuation amid the throng is a difficult task, it involves choices, and our two heroines are undertaking a journey. The beach itself underscores the indeterminate space of adolescence: it is neither land nor sea, just as adolescence is neither childhood nor adulthood. Furthermore the beach underscores societal divisions on the basis of class, ethnicity and subculture.

14 A.M. Hazell Reflections of Reality? female roles in Australian adolescent fiction since World War II, Blackwood SA, Auslib Press, 1989, pp. 65 \& 69. 
student contempt for values of honesty and authenticity, and their ingenuity for subversion, are fully displayed by showing many more of their number with written answers up sleeves, on palms and under skirts. These students comply outwardly, and resist covertly, the values of the school. The four main characters are caught attempting to cheat and are sent to the Principal's office.

The association of school with 'Culture' is emphasised by the presence of 'Art' on the walls of the corridor outside the Principal's office and reinforced by the presence within of a reproduction of The Man with the Golden Helmet, a painting once synonymous with breeding and good taste, (and deliciously heightening the ironic potential of the scene, discovered in 1985, not long after the film was made, not to be by Rembrandt at all!). ${ }^{15}$ This 'Art' though is represented alongside the paraphernalia of school administration: all manner of filing cabinets, two telephones, a school timetable on a noticeboard and so on. The Headmaster (played with stunning pathos and good humour by Bud Tingwell) is a slightly overweight, kindly man worn down by negotiating with resistant teenagers and managing his school.

After Debbie and Sue are proven to be worthy members of the Greenhills gang by not 'dobbing' on the other cheats in the examination, they are invited to the toilets for a cigarette by the cool group's leader, Tracey (Sandy Paul). The toilets are strewn with garbage and there is water all over the floor. Junior girls are evicted without so much as a by-your-leave as the senior girls take over the cubicles. One junior is pressed into service to watch for Mrs Yelland (Kate Shiel), the female teacher on playground duty. They just miss being caught.

However Sue is caught out in a later scene set in Mr Berkhoff's (Andrew Martin) mathematics classroom - where the lesson begins with his admonition: 'Pay attention, it's your future, not mine'. She and Debbie trade notes on the delicate matter of Sue's sexual engagement with her current boyfriend Danny. The note she is forced to surrender to the teacher reads:

I think Danny wants to do it. I don't want him to think I'm just a rooting machine. Do

you reckon I should let him????

This note indicates the real issues of import as far as Debbie and Sue are concerned and these have nothing to do with the acquisition of culture, but everything to do with peer relationships. If the beach in Puberty Blues has been symbolically positioned as 'nature' and the suburb has been positioned as 'culture' with a little ' $c$ ', the high school is shown as the custodian of 'Culture' with a capital ' $C$ '. And like everything else related to the real business of the school and its formal and informal curricula, it is irrelevant. School for the students is for socialising, for subverting and surviving.

\section{The student culture in Puberty Blues: an ethics-free zone}

Puberty Blues presents a warts-and-all portrait of surfie subculture in the 1970s for both girls and boys. The original age of the girls in the book on which the film is based was 13, but Beresford had to raise their ages to 16 in the film because of the risque material depicted. ${ }^{16}$ As with the upper class girls in Beresford's other school-based film, The Getting of Wisdom (1977), the girls of the Greenhills gang are ruthless boundary riders (literally in the case of Cheryl who owns and rides a horse in the film), patrolling the subcultural norms with a vicious concern that denies any fellow feeling. They are the passive sexual playthings of the boys in the group as well as their servants, and provide an audience to active boy surfing culture. Their conversation is basic and focused on

15 O. Friedrich 'The man with the golden helmet', TIME Magazine online 16 Dec. 1985. http://www.time.com/ time/magazine/article/0,9171,960416-2,00.html (accessed 20.11.07.)

16 Carey commented on this disappointing aspect of the film on ABC TV 'The Big Chill': Interview with Lette and Carey 30.9.2000, transcript downloaded from www.ozcinema.com/reviews/p/pubertyblues.html 
boys. Debbie, a bright student, tries to hide her academic ability. She commented on why she needed to join the Greenhills Gang:

If you weren't a surfie chick, you were a nobody - a nerd. If you wanted to get into the gang, you had to crawl after and suck up to all the gang girls.

So Debbie and Sue abandon or surrender their finer feelings, their reservations and their honesty in order to achieve sub-cultural approval. While the portrait of the girls is harsh, however, that of the boys is damning.

The 'boy problem', rediscovered periodically in popular discourse, is graphically outlined in Puberty Blues. The boys pursue their own interests, bodily needs and recreation with homosocial intensity. They are depicted in two main ways. The first way is as empty headed sexual users, epitomised by Debbie's first boyfriend, the working class 'brickie's' labourer, Bruce (Jay Hackett). It is Bruce who is one of three surfie boys who engineer a 'gang bang' with Freda, the outcast girl they have positioned as 'moll', and it is his sexual relations with Debbie that are the height of selfish banality. These teenage males are self-centred sexual predators. Other young males are shown to be overwhelmed victims of parental pressure and drug culture as shown in the figure of Debbie's second boyfriend Garry (Geoff Rhoe), who eventually dies a lonely street death from a heroin overdose. These young people seem to live in a separate moral and ethical universe from everyone else in the film, although this is more so for the boys than the girls.

Both males and females physically assault one another. They lie to their parents and their teachers about their activities. As has been shown both groups freely cheat in school examinations. The fact that Debbie and Sue buy their own surf board and challenge the male hegemony of surfie subculture at the film's end fails to redeem what is essentially a damning portrait of depoliticised and wilfully ignorant Australian youth. Indeed the ending of the film could be read not so much as a feminist affirmation of nascent self authoring by Debbie and Sue, but as a capitulation to middle class capitalist acquisition and me-too 'feminism' where female emancipation from crippling sex roles is achieved by aping male behaviours. Debbie and Sue do not read a book, or go to the theatre, or any other indication that they are orienting themselves away from sub-cultural emptiness - they buy a surfboard. If there is a redemptive and feminist act in the closing scenes of Puberty Blues it is when both girls acknowledge sisterhood with the outcast girl Freda.

\section{The teachers: a study in irrelevance}

While the students are the main characters in the film, the teachers form a squad of background authority figures whose 'authority' only seems to work but in fact is irrelevant to the lives of their charges. There are three main teachers represented in Puberty Blues: the 'Headmaster', Mrs Yelland and Mr Berkhoff, as well as couple of other background 'teachers'. The Headmaster is represented as the head dag. He is ineffectual, too soft, and gives sad little shaming speeches when dealing with students one to one, and over the top melodramatic speeches when in assembly. Mr Berkhoff, the Maths teacher, is vaguely contemptuous, indifferent ('it's your future, not mine') and condescending ('girlie'). Mrs Yelland, the playground duty teacher, and exam invigilator, is represented as a stonefaced, sarcastic warden. The other teachers shown invigilating examinations are suspicious but ineffectual mostly and only catch a few of the cheaters because they spoke. The men all wear Bermuda shorts, long socks, short sleeve business shirts and ties - in short they are all dags. There is a sense that the students live their full lives underneath the teachers' gaze, but are never actually caught authentically in that gaze - they hide in full sight. There is no lovable and learned Mr Chips, no heroic Jaime Escalante from Stand and Deliver (1988), no inspiring John Keating from Dead Poet's Society (1989), no self-sacrificing Mr Holland from Mr Holland's Opus (1995) - just teachers 
containing, rather than changing, their students' lives.

\section{Conclusion}

International researchers, mainly in the United States, are beginning to explore the ways in which cinematic representations of schooling have effects in society. For example, Robert C. Bulman in Hollywood Goes to High School argues that films, like schools themselves, are 'socialising institutions' that shape as well as reflect popular culture. In the United States, he says the hegemonic values of the middle class (individualism, self-sufficiency, free expression, and hard work) are affirmed in Hollywood high school films. ${ }^{17}$ In The Hollywood Curriculum Mary M. Dalton examines the filmic representation of teachers in a range of Hollywood films in terms of curriculum theory. ${ }^{18}$ Employing a cultural studies approach, especially around the concept of intertextuality, she argues that popular culture is inescapable; that popular film offers 'an intersection between the theoretical and the everyday' and that popular film about teachers helps to create real-life teacher-student relationships. ${ }^{19}$ Another North American researcher, Marshall Gregory, also discusses the negative power of cinematic representations of schooling in US films that 'swirl thickly' in society. ${ }^{20}$ It can be assumed that high grossing films such as Puberty Blues have also had their effects on Australians' attitudes to schools.

The comprehensive high school in Puberty Blues is represented as a social space for adolescents to interact. The school exerts little effective discipline on its students, and has no relevance to their lives except as a constraining factor. Its spaces are unattractive and its teachers fighting a losing battle in the face of their students' duplicitous and casual disregard. Furthermore very little learning is shown to occur. This representation, created in the early 1980 s before the middle class leakage away to the private schools became a haemorrhage, ${ }^{21}$ may have added to or at least reinforced negative opinions about the public comprehensive high school, which have gathered strength since 'the residualisation' of such schools in recent years.

Sherington and Campbell have written convincingly about the desertion of the middle class from the comprehensive public high school within the milieu of marketisation of the Australian economy after the 1970s. ${ }^{22}$ Puberty Blues might add a minor note to that analysis in that it suggests two further reasons for that desertion - the first from the making and showing of the film itself and other films like it. This is that the visual images of such schools sent negative messages to aspiring parents about their value. The other reason arises from the film's narrative: this is that Puberty Blues shows how, even before their parents did, some of the children of the middle class had opted

17 R.C. Bulman, Hollywood Goes to High School: cinema schools and American culture, New York, Worth, 2005. See also M.M. Dalton, The Hollywood Curriculum: teachers in the movies, revised edition, New York, Peter Lang, 2004.

18 Dalton, The Hollywood Curriculum.

19 Dalton, The Hollywood Curriculum, pp.2-15.

20 M. Gregory, 'Real teaching and real learning vs narrative myths about education', Arts and Humanities in Higher Education, vol. 6, no. 1, 2007, pp. 7-27.

211976 was the highpoint for middle class participation in state school participation. See C. Campbell, 'Changing school loyalties and the middle class: a reflection on the developing fate of State comprehensive high schooling', The Australian Educational Researcher, vol.32, no.1, April 2005, pp.3-24.

22 C. Campbell and G. Sherington, 'Australian liberalism, the middle class and public education from Henry Parkes to John Howard', Education Research and Perspectives, vol.31, no.2, 2004, pp. 59-77. In this historical overview of Australian liberalism, the middle class and public schooling in New South Wales, the authors outline the rise and demise of the middle class's commitment to public education. They position the increasing abandonment of public schooling by this influential sector of society within macro religious/ philosophical, political, economic and social shifts throughout the nineteenth and twentieth centuries. Roughly, they posit a shift from a Protestant-based moral vision of state action through an expanding public schooling system as a common good, to a market-driven form of Christian liberalism based on 'choice' and 'rights' that favours private schooling. 
out of comprehensive schooling (even as they attended such a school) as a site where any value might be gained, in favour of subculture. In moving away from the comprehensive high school as best for their children, increasingly anxious middle class parents may thus also have been reacting not only to macro shifts in economy and philosophy, but also to negative portrayals of the such schools swirling in the popular culture, as well as to their children's apathetic behaviours within the context of this 'soft' or 'ineffective' schooling. Perhaps in sending their children to a private school, middle class parents were seeking a way to restore their children's faith, and therefore their own, in the credibility of their schools - and as budding consumerists themselves, children of the 1980s and beyond could easily be made to understand that a 'bought' education was somehow more valuable than a free one. Educational value was thus demonstrable in monetary outlay. In the same way Debbie and Sue demonstrate their individuation and imbue their experience as females with value through the purchase of a surf board.

Author: Dr Jo May lectures in history at the University of Newcastle. Her research includes social and cultural perspectives of the history of Australian education. She is Reviews Editor for History of Education Review and a member of the national executive of the International Australian Studies Association.

Email: Josephine.May@newcastle.edu.au 